\title{
PROTOTIPE PENGONTROLAN PINTU GUNA MENGAMANKAN NASKAH SOAL UJIAN NASIONAL PADA SMA NEGERI 11 TANGERANG
}

\author{
Ferry Sudarto, S.Kom ${ }^{1}$ \\ Eka Purwandari ${ }^{2}$ \\ Aldien Sora Andrea ${ }^{3}$ \\ Dosen Jurusan Sistem Komputer STMIK Raharja ${ }^{1}$, Alumni STMIK Raharja Jurusan Sistem \\ Komputer $^{2}$, Mahasiswa STMIK Raharja Jurusan Teknik Informatika ${ }^{3}$ \\ Email:ferry.sudarto@ raharja.info, eka@raharja.info, aldien@ raharja.info
}

Diterima: 4 Januari 2018/ Disetujui : 22 Januari 2018

\begin{abstract}
Research on "PROTOTYPE DOOR CONTROLLING TO SAVE NATIONAL EXAM SCRIPT AT 11 SENIOR HIGH SCHOOL TANGERANG" aims to provide security benefits in the national exam deception problems. This research was carried out by making a prototype in the form of a door with a security system using technologies of embedded systems. Namely to control a door through Android smartphone. This is because the security system is not running optimally so often lead to deception. Therefore, we need a system to facilitate and secure the national examination script. All this time during the security room to store national test script using only a padlock. This research will provide an overview of the complex mechanisms such as how a door will lock securely using an application on Android smarthphone as the key. The prototype uses a door control basic 4 android as an interface between users. By using Bluetooth as a sensor signal to the sender to call the personal computer ( $p c)$ database and added arduino uno as a DC motor controllers. Prototype controlling these doors can be a reference to the department in dealing with security issues manuscript national exam.
\end{abstract}

Keywords: Door, Smartphone, National Exam.

\begin{abstract}
ABSTRAKSI
Penelitian tentang "PROTOTIPE PENGONTROLAN PINTU GUNA MENGAMANKAN NASKAH SOAL UJIAN NASIONAL PADA SMA NEGERI 11 TANGERANG" bertujuan untuk memberikan manfaat keamanan dalam permasalahan kebocoran soal ujian nasional. Penelitian ini dilakukan dengan cara membuat sebuah prototipe berupa sebuah pintu dengan sistem keamanan menggunakan teknologi embedded system. Yaitu dengan mengontrol sebuah pintu melalui smartphone android. Hal ini dikarenakan sistem keamanan yang belum berjalan maksimal hingga sering menimbulkan kecurangan. Dengan adanya hal tersebut maka diperlukan suatu sistem untuk memudahkan dan mengamankan naskah ujian nasional. Jika selama ini pengamanan ruang untuk menyimpan naskah ujian nasional hanya menggunakan sebuah gembok. Penilitian ini akan memberikan gambaran umum tentang mekanisme yang kompleks seperti bagaimana sebuah pintu akan mengunci dengan aman menggunakan sebuah aplikasi pada smarthphone android sebagai kuncinya. Prototipe pengontrolan pintu ini menggunakan basic 4 android sebagai interface antara pengguna. Dengan menggunakan bluetooth sebagai sensor pengirim sinyal ke personal computer $(P C)$ untuk memanggil database dan ditambah arduino uno sebagai pengendali motor DC. Prototipe pengontrolan pintu ini dapat menjadi acuan untuk jurusan dalam menangani permasalahan keamanan nashkah ujian nasional (UN).
\end{abstract}

Kata Kunci: Pintu, Smartphone, Ujian Nasional.

\section{PENDAHULUAN}

Ujian Nasional atau yang sering kita sebut UN merupakan suatu kebijakan pemerintah dalam bidang pendidikan untuk menentukan standar kelulusan di Indonesia sesuai dengan peraturan Menteri 
Pendidikan Nasional RI No. 45 Th 2006 tentang Ujian Nasional (UN) tahun pelajaran 2006/2007. Ketetapan nilai minimal standar kelulusan ujian nasional ditingkatkan setiap tahun oleh pemerintah hingga saat ini ditetapkan sebesar 5,5 sebagai nilai minimal. Fungsi ujian nasional sendiri adalah untuk mendongkrak kualitas pendidikan di Indonesia dengan kata lain sebagai quality control.

Namun di sisi lain ujian nasional adalah satu momok yang menakutkan pada kalangan pelajar serta orang tua. Hasil ujian nasional yang dijadikan indikator kelulusan sekolah membawa dampak psikologis yang cukup berat. Dari hal tersebut dapat menimbulkan praktek-praktek manipulasi atau kecurangan yang sengaja dibuat atas ketidakpercayaan-diri. Walaupun pengawasan naskah soal ujian nasional sangat ketat keamanannya, tetap ada saja oknum yang membocorkan naskah soal ujian nasional dan dijadikan sebagai alat pemberdaya manusia.

Saat ini pihak sekolah maupun pemerintah hanya menggunakan keamanan sederhana berupa gembok pada pintu serta tenaga keamanan tambahan. Sudah saatnya teknologi berperan sebagai sistem keamanan yang mumpuni. Dilandasi hal tersebut maka dari itu penelitian bermaksud membuat sebuah model kendali pintu otomatis menggunakan smartphone android sebagai kuncinya.

\section{TUJUAN DAN MANFAAT}

\section{a. Tujuan}

1. Menghasilkan sistem keamanan yang praktis dan nyaman dalam sistem yang dibuat.

2. Untuk meningkatkan keamanan atas kebocoran naskah soal ujian nasional.

3. Mengaplikasikan teknologi pada bidang penanganan keamanan pintu sehingga pemanfaatan teknologi pada bidang ini dapat menjadi lebih berkembang.

\section{b. Manfaat}

1. Memberikan kemudahan bagi petugas penjaga pintu keamanan untuk bisa mengontrol.

2. Mengurangi kecurangan atau kebocoran naskah soal ujian nasional.

\section{PERMASALAHAN}

Sistem keamanan dalam bidang pendidikan saat ini khususnya pengamanan naskah soal Ujian Nasional (UN) harus ditingkatkan lagi karena seringnya terjadi kebocoran. Kebocoran naskah soal Ujian Nasional dapat menyebabkan bobroknya pendidikan di Indonesia. Pintu yang hanya diberi segel dan kunci pengaman yang biasa tidak menjamin aman dari kecurangan. Dibutuhkan suatu sistem keamanan yang lebih efisien dan terhindar dari kecurangan. Prototipe ini dirancang untuk bekerja sebagai pengaman yang lebih efisien dari sistem yang lama. Dengan adanya prototipe ini diharapkan adanya peningkatan keamanan dalam bidang pendidikan terutama naskah soal Ujian Nasional (UN). Dengan memanfaatkan Smartphone Android sebagi kuncinya.

\section{RUMUSAN MASALAH}

Dalam rumusan masalah ini memuat uraian secara rinci dari permasalahan yang di identifikasi pada latar belakang, adapun rumusan masalah dalam penyusunan penelitian ini sebagai berikut:

1. Apakah sistem ini dapat meningkatkan kinerja keamanan yang lebih efisien?

2. Apakah dengan adanya sistem akan berpengaruh terhadap peningkatan keamanan dalam bidang pendidikan, terutama keamanan naskah soal ujian nasional (UN)? 


\section{LANDASAN TEORI}

\section{a. Android}

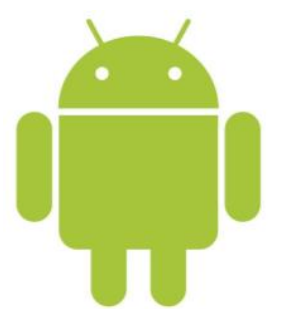

Gambar 1. Logo android

Menurut Nazruddin (2011:1), "android adalah sistem operasi yang berbasis linux untuk telepon seluler seperti telepon pintar dan komputer tablet." Android menyediakan platform terbuka bagi para pengembang untuk menciptakan aplikasi mereka sendiri untuk digunakan oleh bermacam peranti bergerak. Awalnya, google inc. membeli android inc., pendatang baru yang membuat peranti lunak untuk ponsel. Kemudian untuk mengembangkan android, dibentuklah open handset Alliance, konsorsium dari 34 perusahaan peranti keras, peranti lunak, dan telekomunikasi, termasuk google, HTC, intel, luetoot, qualcomm, T-mobile, dan nvidia.

\section{b. Basic 4 Android}

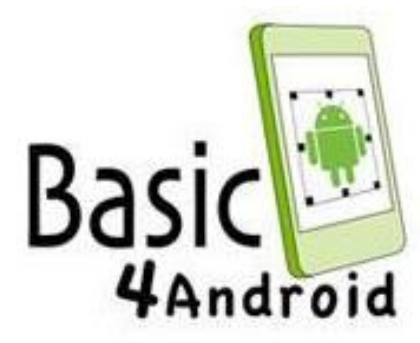

\section{Gambar 2. Basic 4 android}

Basic 4 android adalah development tool sederhana yang powerful untuk membangun aplikasi android. Bahasa basic 4 android mirip dengan bahasa visual basic dengan tambahan dukungan untuk objek. Aplikasi android (APK) yang di compile oleh basic 4 android adalah aplikasi android native/asli dan tidak ada extra runtime seperti di visual basic yang ketergantungan file msvbvm60.dll, yang pasti aplikasi yang luetooth oleh basic 4 android adalah No Dependencies (tidak ketergantungan file oleh lain). IDE basic 4 android hanya luet pada development android.

Basic 4 android termasuk designer GUI untuk aplikasi android yang powerful dengan dukungan built-in untuk multiple screens dan orientations, serta tidak dibutuhkan lagi penulisan XML yang rumit, dapat di develop dan debug dengan emulator android atau dengan real device (koneksi ke USB atau melalui local network).

\section{c. Bluetooth HC-05}

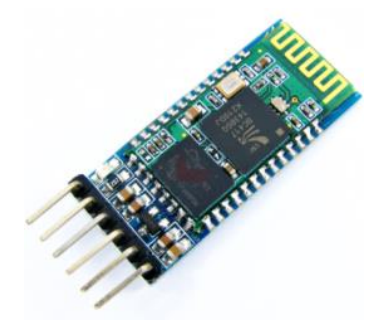

Gambar 3. Bluetooth HC-05 
Menurut Yogyo Susaptoyono (2012:5), "bluetooth adalah teknologi yang memungkinkan dua perangkat yang kompatibel, seperti telepon dan PC untuk berkomunikasi tanpa kabel dan tidak memerlukan koneksi saluran yang terlihat. Teknologi ini memberikan perubahan yang bluetooth sesungguhnya merupakan spesifikasi luetoot untuk jaringan wilayah pribadi nirkabel (WPAN)". Bluetooth menfasilitasi koneksi dan pertukaran informasi di antara alat-alat seperti PDA, ponsel, komputer laptop, printer, dan kamera digital melalui frekuensi radio jarak dekat.

\section{d. Arduino Uno}

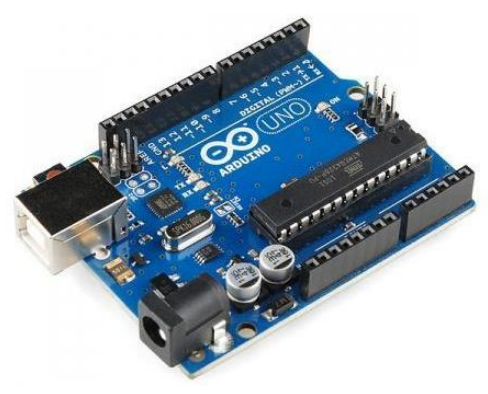

Gambar 4. Arduino uno

Menurut Djuandi (2011), "arduino adalah sebuah board mikrokontroller yang berbasis Atmega328". Arduino memiliki 14 pin input/output yang mana 6 pin dapat digunakan sebagai output PWM, 6 analog input, crystal osilator $16 \mathrm{MHz}$, koneksi USB, jack power, kepala ICSP, dan tombol reset. Arduino mampu men-support mikrokontroller; dapat dikoneksikan dengan komputer menggunakan kabel USB.

\section{LITERATURE REVIEW}

Banyak penelitian yang sebelumnya dilakukan mengenai pengontrolan pintu dan penelitian lain yang berkaitan. Dalam upaya mengembangkan dan menyempurnakan pengontrolan pintu ini perlu dilakukan studi pustaka (literature review) sebagai salah satu dari penerapan metode penelitian yang akan dilakukan. Diantaranya yaitu :

1. Penelitian ini dilakukan oleh Arif ${ }^{[1]}$ dari Sekolah Tinggi Manajemen Dan Ilmu Komputer (STMIK) RAHARJA, Pada Laporan Skripsi tahun 2014 yang berjudul "DESAIN PROTOTIPE SMART VOICE DEVICE PINTU RUANGAN MENGGUNAKAN RASPBERRY PI PADA PERGURUAN TINGGI RAHARJA". Penelitian ini membahas tentang prototipe pintu ruangan menggunakan voice command yang dapat mengurangi jumlah tindak kriminalitas pembobolan pintu ruangan, alat ini menggunakan suara si pengguna sebagai akses untuk membuka dan menutup pintu ruangan.

2. Penelitian ini dilakukan oleh Alpurqon ${ }^{[2]}$ dari Sekolah Tinggi Manajemen Dan Ilmu Komputer (STMIK) RAHARJA, Pada Laporan Skripsi tahun 2014 yang berjudul "SISTEM PENGENDALI PINTU PAGAR SECARA OTOMATIS MENGGUNAKAN APLIKASI VOICE COMMAND PADA SMARTPHONE ANDROID OS”. Penelitian ini membahas tentang sistem mekanik pengendali pintu pagar secara otomatis yang diintergrasikan pada smartphone, dan memudahkan untuk membuka dan menutup pintu pagar rumah kita secara otomatis.

3. Penelitian ini dilakukan oleh Sepiawan ${ }^{[3]}$ dari Universitas Brawijaya, Pada Laporan Jurnal Ilmiah tahun 2011 yang berjudul "SISTEM KEAMANAN PINTU PAGAR OTOMATIS MENGGUNAKAN VOICE RECOGNITION". Penelitian ini membahas tentang keamanan pada pintu. System ini menggunakan sensor pengolah suara Easy VR, sehingga mampu menjadi pengaman berupa password yang lebih menguntungkan.

4. Penelitian ini dilakukan oleh Nedia ${ }^{[4]}$ dari Universitas Andalas, Pada Laporan Jurnal Ilmiah tahun 2012 yang berjudul "SISTEM PENGONTROLAN PINTU GARASI RUMAH MENGGUNAKAN KOMUNIKASI DTMF MELALUI PONSEL BERBASIS 
MIKROKONTROLLER ATMEGA32". Penelitian ini membahas tentang sistem pengontrolan pintu garasi pada rumah menggunakan komunikasi DTMF melalui handphone. Manfaat yang didapat dari sistem ini adalah dapat mempermudah pekerjaan manusia dalam mengontrol rumah secara otomatis dari jarak jauh.

5. Penelitian ini dilakukan oleh Hendru ${ }^{[5]}$ dari Universitas Tarumanegara, Pada Laporan Skripsi tahun 2012 yang berjudul "PERANCANGAN SISTEM KONTROL PINTU GERBANG OTOMATIS". Penelitian ini membahas tentang pintu gerbang otomatis dirancang dengan tingkat keamanan yang tinggi dikarenakan fungsinya yang sangat penting. Penggunaan dan pengaturan sensor menjadi unsur utama dalam metode pengendalian pintu gerbang otomatis.

6. Penelitian ini dilakukan oleh Surya ${ }^{[6]}$ dari Universitas Negeri Padang, Pada Laporan Skripsi tahun 2012 yang berjudul "PERANCANGAN DAN PEMBUATAN SISTEM KEAMANAN PINTU RUANGAN TEMPAT PENYIMPANAN BARANG JAMINAN MENGGUNAKAN RADIO FREQUENCY IDENTIFICATION (RFID) DAN SHORT MESSAGE SERVICE (SMS) BERBASIS MIKROKONTROLER AT89S52". Penelitian ini membahas tentang merancang suatu prototipe sistem keamanan pintu tempat penyimpanan barang jaminan pada kantor Pegadaian secara otomatis berdasarkan input dari keypad.

7. Penelitian ini dilakukan oleh Muthiah ${ }^{[7]}$ dari Universitas Negeri Yogyakarta, Pada Laporan Tugas Akhir tahun 2014 yang berjudul "PROTOTYPE PENGAMAN PINTU RUMAH BERBASIS MIKROKONTROLER ATMEGA 16". Penelitian ini membahas tentang perancangan sebuah alat elektronika berbasis mikrokontroler yang dikendalikan oleh bahasa pemograman assembler yang dapat menggerakkan motor stepper sebagai pengunci agar pintu dapat terbuka secara otomatis dan semua indikasi yang terkombinasi dengan alat dapat diaktifkan dengan menggunakan password.

8. Penelitian ini dilakukan oleh Bagenda ${ }^{[8]}$ dari STMIK LPKIA, Pada Laporan Jurnal Ilmiah tahun 2011 yang berjudul "PROTOTIPE SISTEM KEAMANAN PINTU GARASI MENGGUNKAN KEYPAD DENGAN SENSOR BERBASIS MIKROKONTROLLER". Penelitian ini membahas tentang pengoperasian pintu gerbang otomatis menggunakan keypad dan sensor yang berfungsi sebagai pengatur, dalam artian mebuka pintu garasi dan medeteksi objek manusia yang berada di garis pintu garasi.

9. Penelitian ini dilakukan oleh Riadi ${ }^{[9]}$ dari Universitas Ahmad Dahlan, Pada Laporan Jurnal Ilmiah tahun 2014 yang berjudul "PROTOTIPE SISTEM KEAMANAN PINTU RUANGAN MENGGUNAKAN BARCODE PASSWORD DAN PIN PASSWORD”. Penelitian ini membahas tentang sebuah prototipe sistem keamanan pintu ruangan menggunakan barcode password dan pin password. metode yang digunakan untuk membuka dan menutup pintu adalah metode penyesuaian label barcode yang terdapat pada kartu id dan pin dengan data yang terdapat pada database.

10.Penelitian ini dilakukan oleh Undala ${ }^{[10]}$ dari Universitas Tanjungpura, Pada Laporan Jurnal Ilmiah tahun 2015 yang berjudul "PROTOTYPE SISTEM KEAMANAN PINTU MENGGUNAKAN RADIO FREQUENCY IDENTIFICATION (RFID) DENGAN KATA SANDI BERBASIS MIKROKONTROLLER". Penelitian ini membahas tentang sistem pengaman pintu dibuat secara bertahap dan langsung. Sistem keamanan bertahap dipakai sebagai pengganti kunci utama dengan fungsi fitur kunci ganda menggunakan kata sandi melalui keypad untuk membuka kunci pintu, sedangkan sistem keamanan langsung dipakai ketika dalam keadaan darurat atau sebagai pengganti kunci cadangan untuk membuka pintu secara langsung tanpa menggunakan kata sandi.

Dari kesepuluh literature review yang ada, telah banyak penelitian mengenai pengontrolan pintu. Namun dapat disimpulkan pula bahwa belum ada peneliti yang secara khusus membahas atau mengatasi masalah mengenai sistem pengontrolan pintu menggunakan android untuk mengamankan naskah ujian nasional (UN). 


\section{METODE PENELITIAN}

Metode pengembangan sistem yang digunakan oleh penulis adalah model prototype jenis I. Prototype memberikan ide bagi pembuat maupun pemakai potensial tentang cara sistem akan berfungsi dalam bentuk lengkapnya. Adapun langkah-langkah pada model prototype jenis I sebagaimana yang dikemukakan oleh Raymond McLeod Jr. adalah sebagai berikut:

\section{Mengidentifikasikan kebutuhan pemakai}

Analis sistem mewawancarai pemakai untuk mendapatkan gagasan dari apa yang diinginkan pemakai terhadap sistem.

\section{Mengembangkan Prototype}

Analis sistem mungkin bekerjasama dengan spesialis informasi lain, menggunakan satu atau lebih peralatan prototype untuk mengembangkan sebuah prototype.

\section{Menentukan apakah prototype dapat diterima}

Analis mendidik pemakai dalam penggunaan prototype dan memberikan kesempatan kepada pemakai untuk membiasakan diri dengan sistem, tahap pengujian.

\section{Menggunakan prototype}

Prototype ini menjadi sistem yang dapat di operasionalkan, tahap implementasi sistem.

Untuk lebih jelasnya dapat dilihat pada gambar pengembangan prototype jenis I, berikut ini:

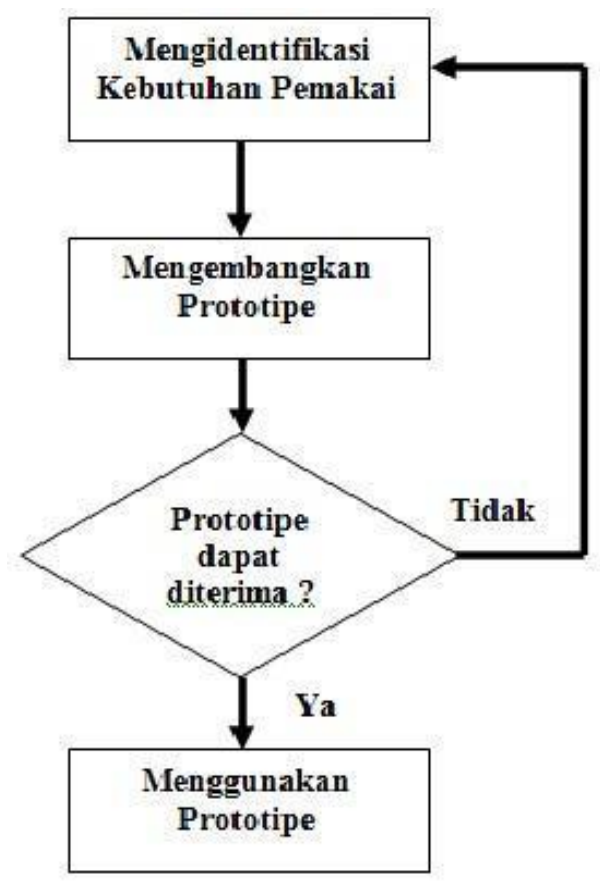

Gambar 5. Pengembagan prototyping jenis 1 (Raymond McLeod Jr. (2001 : 151)

\section{a. Analisis Kebutuhan}

Analisis kebutuhan adalah sebuah proses untuk mendapatkan informasi, model, spesifikasi tentang komponen-komponen apa saja yang dibutuhkan. Pada tahap ini merupakan teknik pemecahan masalah yang bertujuan menyempurnakan kebutuhan-kebutuhan yang ada untuk memastikan seberapa bagus komponen-komponen tersebut bekerja. Ada beberapa point penting untuk menunjang sistem dapat berjalan dengan baik. Sebagai contoh salah satunya adalah petugas yang mempunyai wewenang harus mempunyai hak akses, dalam hal ini mempunyai ID login sebagai kunci. 


\section{b. Perancangan}

Sistem yang akan dibuat pertama kali harus didesain sebelum proses hardware dan coding. Desain sistem yang akan dibuat yaitu meliputi desain interface (antar muka), database, sampai hardware.

\section{PERANCANGAN BLOK DIAGRAM}

Perancangan blok diagram untuk memperingkas gabungan antara masukan dan keluaran dari suatu model yang akan dibuat.

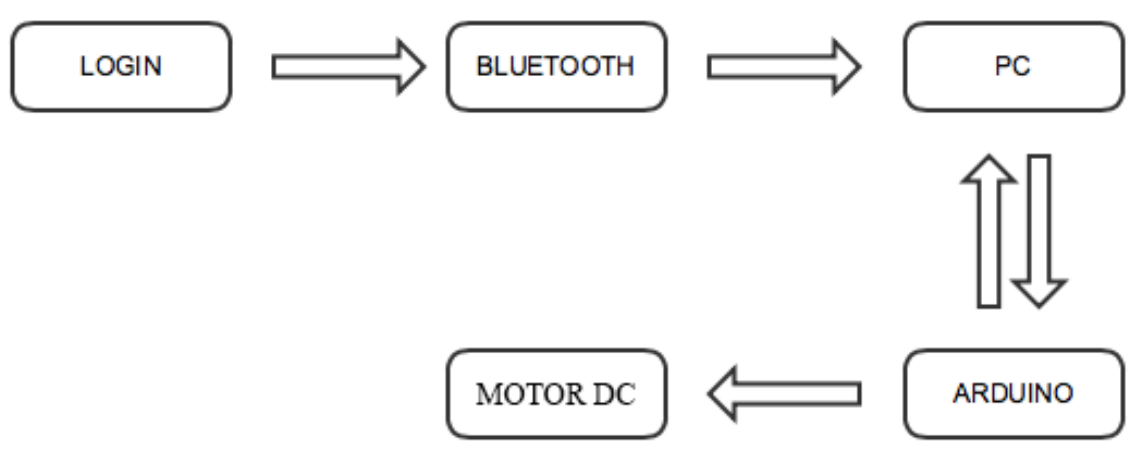

Gambar 6. Perancangan blok diagram

Dimulai petugas melakukan login dengan aplikasi smartphone yang sudah dirancang dengan basic 4 android, lalu sinyal dikirim melalui bluetooth yang diteruskan ke PC untuk mencari database, setelah data ditemukan makan akan dikirim lagi ke arduino menggunakan komunikasi serial untuk memutar motor dan membuka pintu.

\section{PERANCANGAN KENDALI MOTOR DC}

Pada tahap ini dilakukan perancangan mkendali Motor DC untuk mengetahui apakah Arduino dapat mengendalikan putaran Motor DC dengan baik. Arduino menggunakan mikrokontroller ATMega328 dan motor DC.

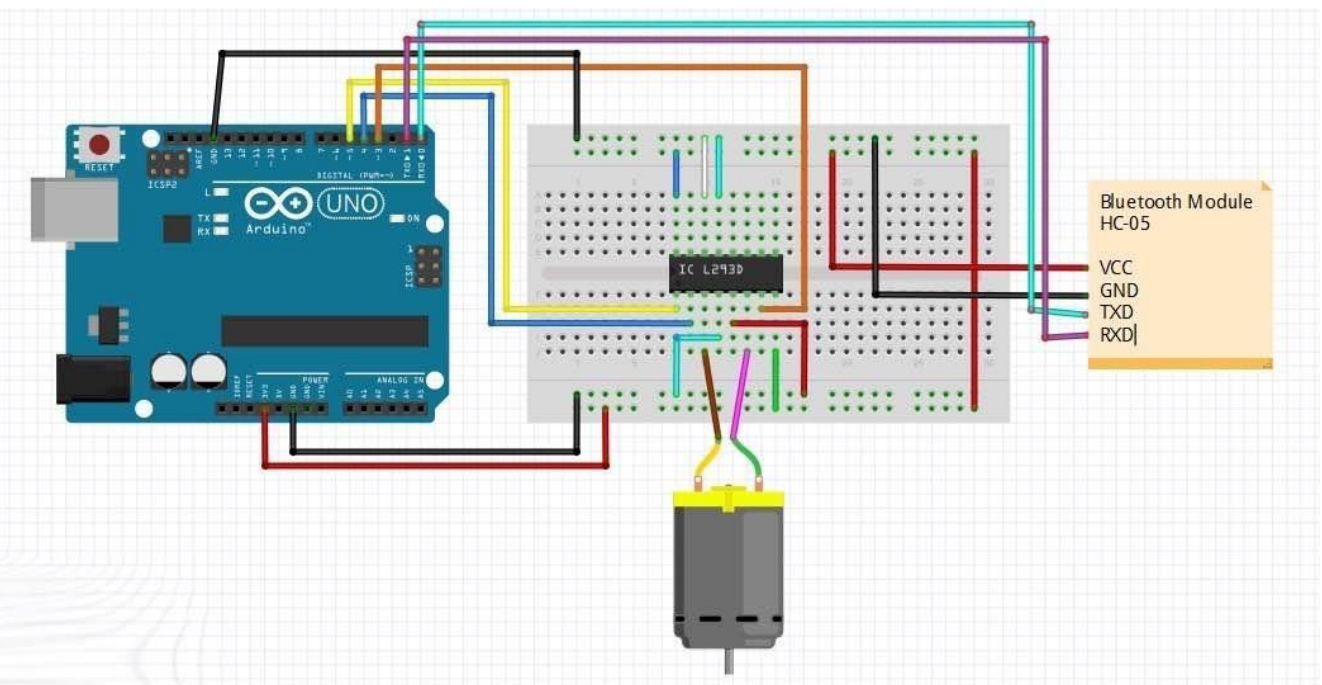

Gambar 7. Skema perancangan kendali motor DC 


\section{PERANCANGAN INTERFACE}

Pada perancangan ini digunakan software basic 4 android untuk mendesain aplikasi pembuka atau pengunci pintu yang terdiri dari beberapa tombol seperti lock, unlock, password, dll. Aplikasi ini diberi nama yaitu, smart lock.

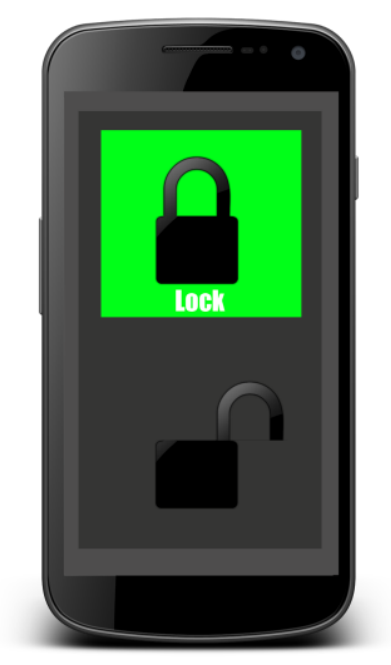

Gambar 8. Aplikasi smart lock

\section{PEMBAHASAN}

\section{DIAGRAM BLOK SISTEM}

Penelitian ini bertujuan untuk merancang dan membuat sebuah prototipe berbasis arduino uno, dengan memanfaatkan smartphone android sebagai kunci dan bluetooth sebagai penghubung sinyal untuk diproses lebih lanjut dan menghasilkan input berupa gerak motor DC.

Agar mudah dipahami, maka peneliti membuat diagram blok sistem dan berserta alur kerjanya untuk sistem pengontrolan pintu guna mengamankan naskah soal ujian nasional pada gambar 9, berikut pembahsannya :

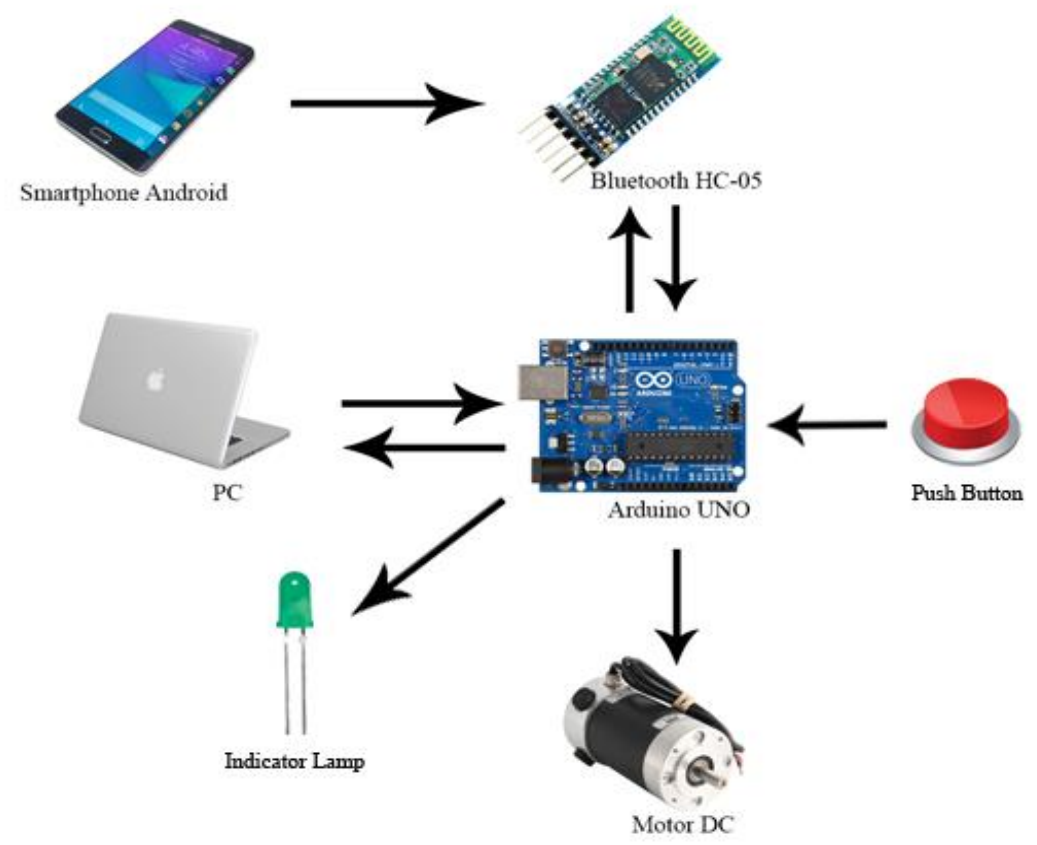

Gambar 9. Diagram Blok Sistem 
Keterangan dan penjelasan diagram blok sistem diatas adalah sebagai berikut:

1. Smartphone sebagai pengontrol untuk mengunci atau membuka pintu.

2. Bluetooth merupakan penghubung sinyal dan akan mengirimkan data dari smartphone Android ke Arduino Uno.

3. Arduino Uno merupakan perangkat yang digunakan untuk menjalankan aplikasi atau perintah program.

4. Personal Computer (PC) sebagai penyimpan database yang berisi data untuk login.

5. Motor DC merupakan sebagai penggerak kunci pintu.

6. Push Button digunakan sebagai tombol alternative ketika input-an perintah suara tidak teridentifikasi.

7. Indicator Lamp digunakan sebagai indikasi jika alat beroperasi dengan baik.

\section{FLOWCHART SISTEM}

Pada pembuataan sebuah kontrol diperlukan sebuah gambar yang akan menjelaskan alur atau langkah-langkah dari sebuah kerja sistem yang dibuat, sehingga dapat memberikan penjelasan dalam bentuk gambar. Penjelasan yang berupa gambar proses kerja sebuah sistem merupakan gambar dari sistem yang akan dibuat. Tujuan dari pembuatan flowchart adalah untuk mempermudah pembaca dan pembuat sistem itu sendiri untuk memahami langkah-langkah serta cara kerja sebuah sistem yang dibuat. Dari penelitian yang dilakukan menghasilkan flowchart sebagai berikut :

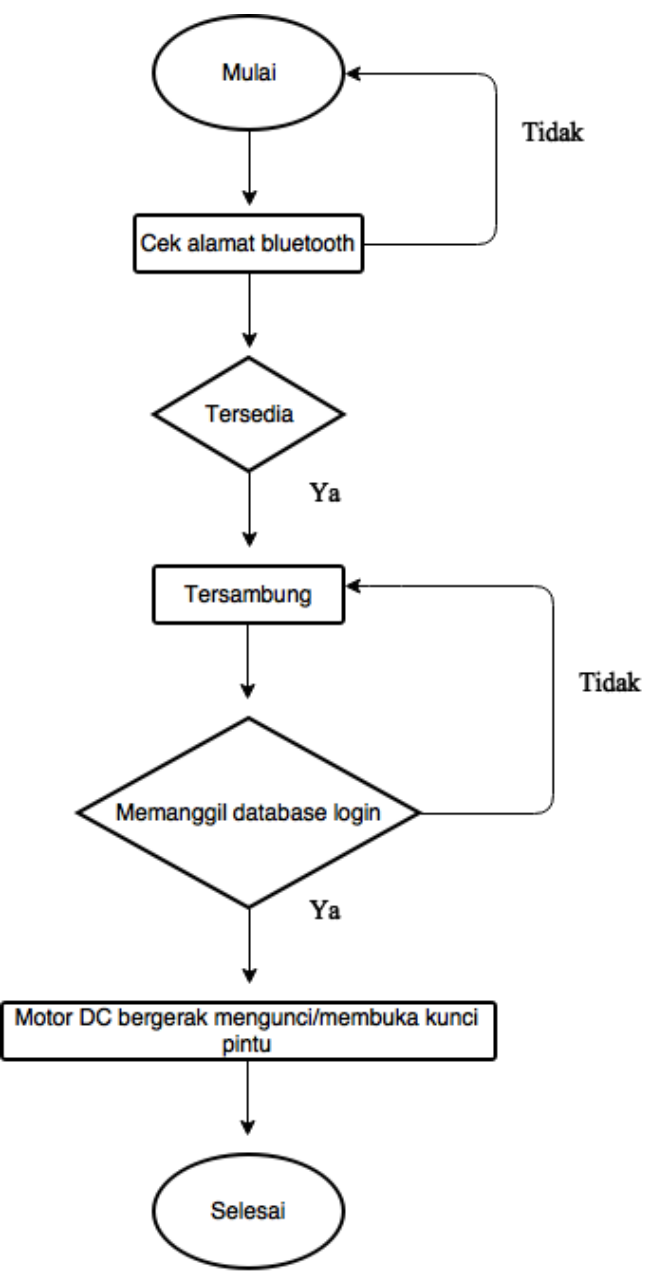

Gambar 10. Flowchart Sistem Pengontrolan Pintu

Program diawali dengan start yang berarti sistem akan mulai bekerja, lalu sistem akan mencari alamat bluetooth. Setelah terhubung dilanjutkan dengan proses input dengan melakukan 
login, kemudian akan memanggil data yang cocok dengan database login. Jika semua proses selesai kemudian motor DC diperintah untuk bergerak mengunci atau membuka kunci sebagai outputnya.

\section{KOMPONEN ALAT}

Di dalam rancangan ini terdapat keseluruhan rangkaian elektronika dan perangkat keras yang disusun sesuai fungsi dan kesesuaian rangkaian yang satu dengan yang lainnya. Berikut penjelasannya:

\section{a. Rangkaian Prototipe alat}

Ini adalah rangkain keseluruhan prototipe alat untuk pengontrolan pintu guna mengamankan naskah soal ujian nasional, pada rangkaian ini terdapat motor DC yang berkerja sebagai penggerak kunci pintu, dan tombol push button berfungsi sebagai tombol emergency ketika smartphone tidak dapat terkoneksi dengan bluetooth. Jika lampu menandakan berwarna hijau, maka bluetooth telah terhubung dengan smartphone, dan kemudian bisa langsung masukkan password.

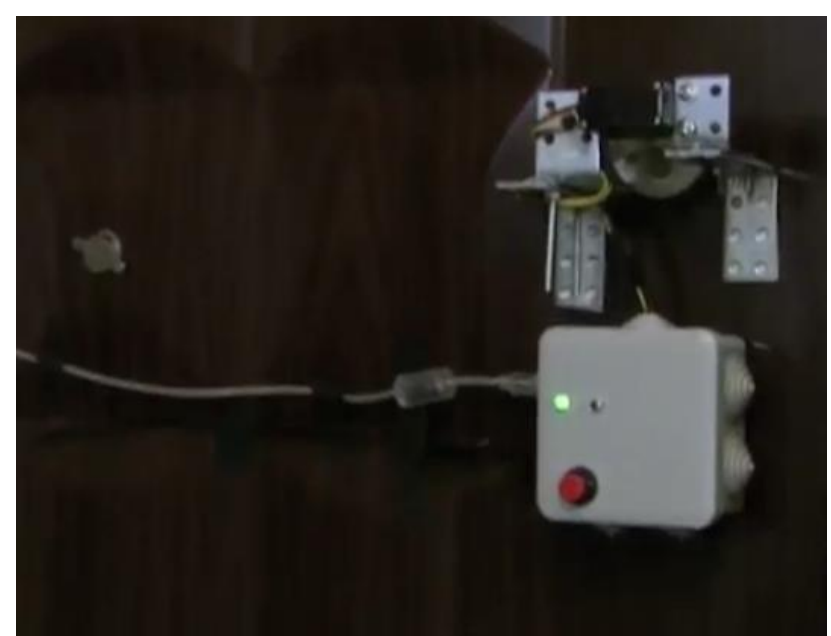

Gambar 11. Rangkaian prototipe alat

\section{b. Input Password Untuk Membuka Pintu}

Sebagaimana gambar 11 yang telah ditunjukan diatas, bahwa ketika lampu telah menandakan berwarna hijau, maka bluetooth telah terhubung dengan smartphone, dan kemudian bisa langsung masukkan password. Password yang telah di-setting pada alat ini yaitu 1234. Setelah password yang sudah dimaasukkan cocok, dengan delay waktu 5 detik maka pintu akan langsung terbuka.

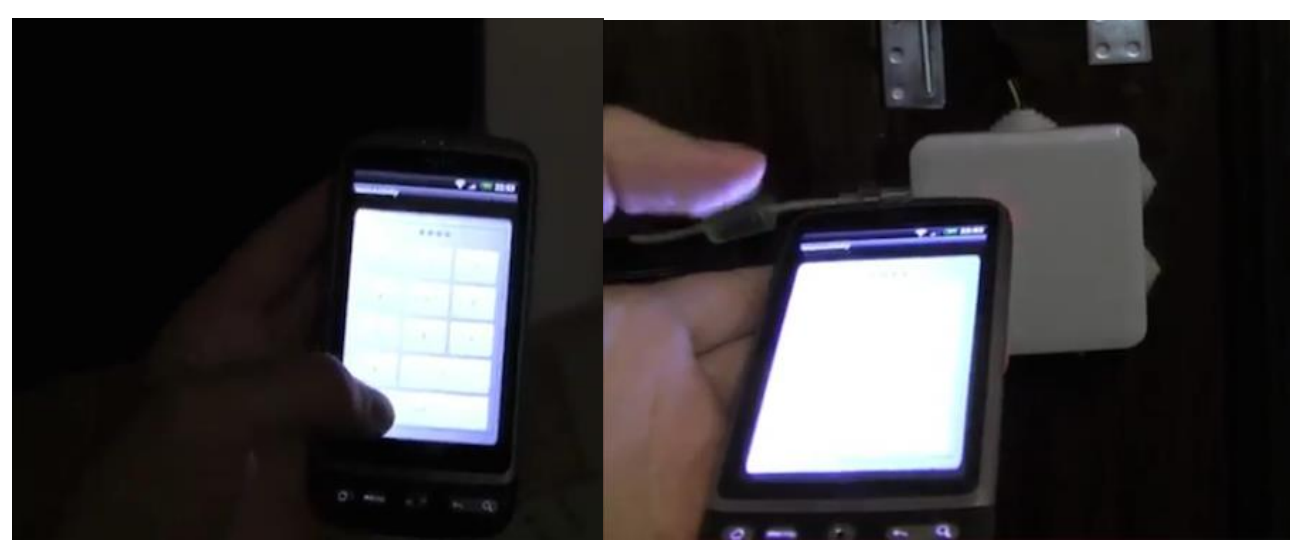

Gambar 12. Proses pada saat membuka pintu 


\section{c. Door Locked}

Setelah selesai menggunakan ruangan, maka hendaknya langsung mengkunci pintu agar segala berkas-berkas yang berada di dalam ruangan tersimpan dengan aman. Berikut ini adalah sebuah interface ketika pintu telah terkunci.

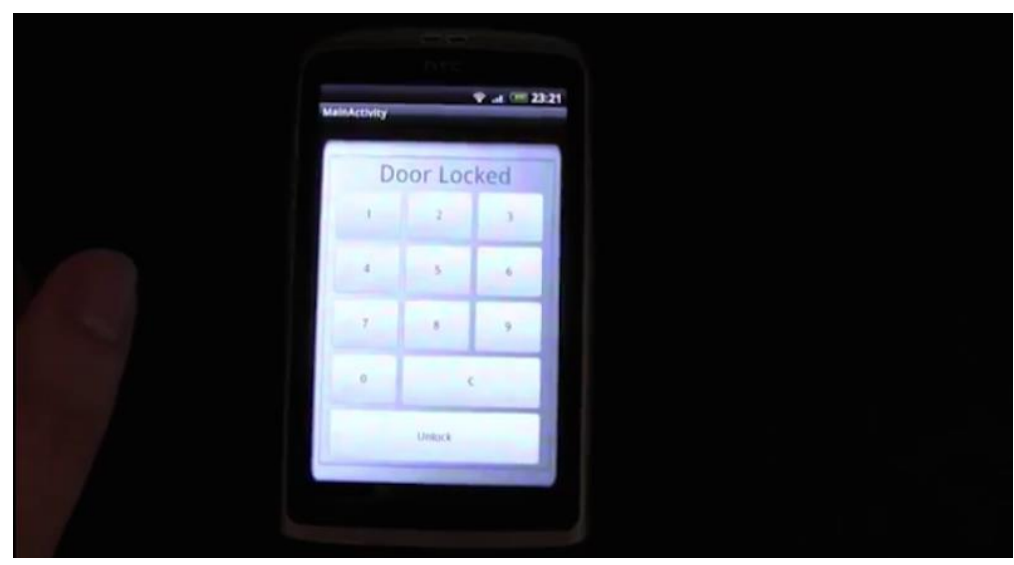

Gambar 13. Interface pada saat pintu telah terkunci

\section{CARA KERJA ALAT}

Alat yang diperintah untuk mengunci pintu pertama kali yang harus dilakukan adalah membuka aplikasi Smart Lock lalu pilih perintah Lock kemudian akan masuk ke tahap login, masukan password sesuai yang telah ditentukan oleh bagian keamanan, tap tombol Lock lalu pintu akan terkunci. Untuk gambaran lebih jelasnya, lihat gambar di bawah:

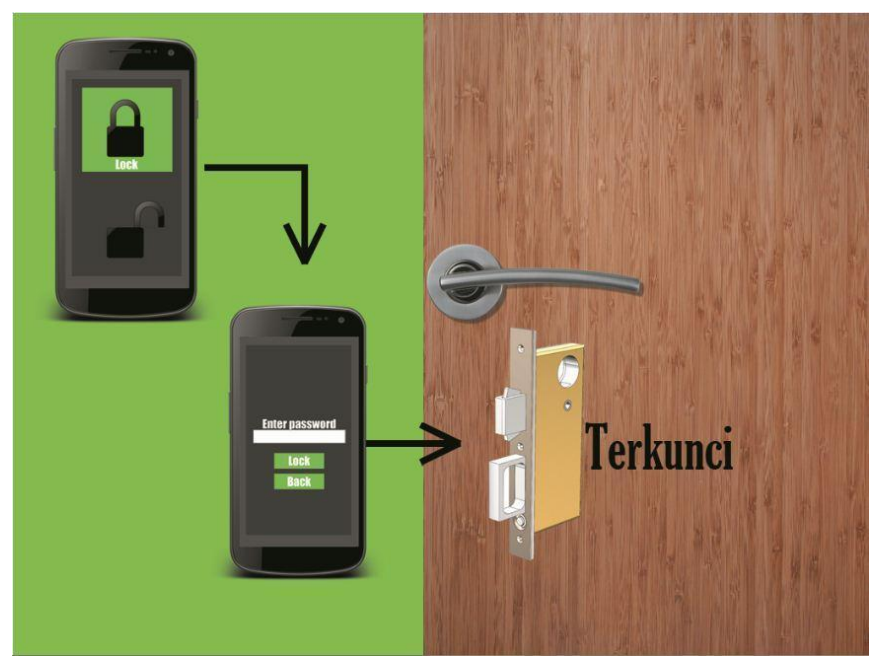

\section{Gambar 14. Cara kerja pengontrolan smart lock saat terkunci}

Alat yang diperintah untuk membuka kunci pintu pertama kali yang harus dilakukan adalah membuka aplikasi Smart Lock lalu pilih perintah Unlock kemudian akan masuk ke tahap login, masukan password sesuai yang telah ditentukan oleh bagian keamanan, tap tombol Unlock lalu pintu akan membuka kunci. Untuk gambaran lebih jelasnya, lihat gambar di bawah ini : 


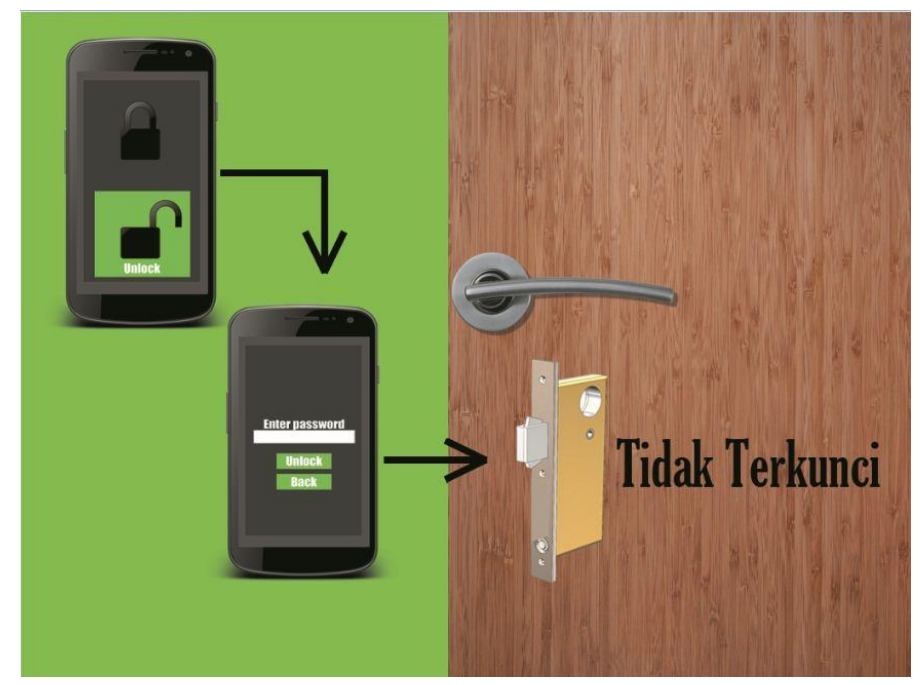

Gambar 15. Cara kerja pengontrolan smart lock saat tidak terkunci

\section{EKSEKUSI PROGRAM}

Untuk mengeksekusi program sebelumnya perlu menginstall driver papan arduino pada PC. Caranya cukup mudah, hanya dengan menyambungkan papan arduino dengan sebuah PC melalui kabel USB, lalu komputer akan mendeteksi sebuah perangkat baru. Setelah melalui proses installasi selesai jalankan IDE (integrated development environment) Arduino dengan menjalankan sebuah file bernama arduino.exe pada lokasi software arduino. IDE digunakan untuk membuat program dan menjalankan program tersebut. Jalankan menu Tools-Board, kemudian pilih arduino genuine/uno. Selanjutnya masukan kode ke dalam program untuk menjalankan alat. Setelah proses pemrograman selesai, klik Upload pada toolbar untuk diupload ke papan arduino dan alat akan jalan. Kode yang deprogram untuk lebih jelasnya dijelaskan pada gambar di bawah:

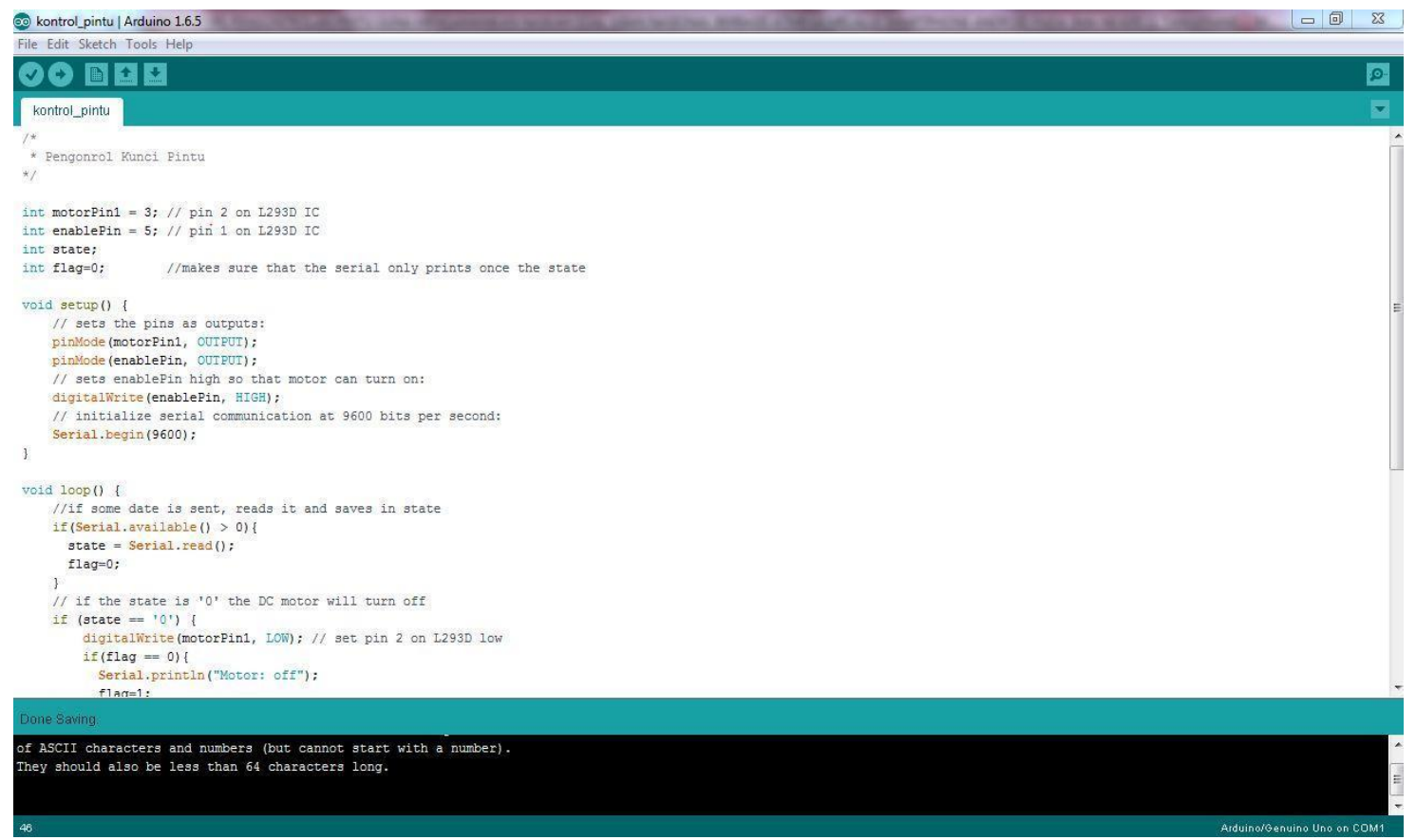

Gambar 16. Eksekusi program pada IDE arduino 


\section{KESIMPULAN}

Setelah dilakukan perancangan, pembuatan dan eksekusi program pada penilitian ini maka dapat disimpulkan bahwa sistem keamanan dalam menyimpan naskah Ujian Nasional (UN) belum menggunakan sistem terkomputerisasi. Sistem keamanan untuk menjaga naskah soal Ujian Nasional (UN) masih menggunakan kunci manual seperti gembok dan adanya resiko kebocoran soal Ujian Nasional (UN), artinya sistem tersebut belum efektif dan efisien. Maka prototipe ini diciptakan menggunakan Arduino Uno berbasis ATMega328 sebagai pemroses semua perintah dari input, dengan menggunakan aplikasi Smartlock yang dibuat untuk Smartphone Android sebagai pengunci dan pembuka kunci.

Setelah Arduino memproses maka output yang dihasilkan adalah sebuah motor DC akan bergerak sesuai dengan perintah (mengunci atau membuka kunci). Dengan prototipe ini diharapkan akan lebih efisien dalam hal keamanan pintu ruangan dimana naskah soal Ujian Nasional (UN) disimpan. Tidak ada lagi kecurangan akibat bocornya naskah soal Ujian Nasional (UN). Mudah dalam pengoperasian alat ini dengan dirancang interface yang menarik dan aman sebagai sistem keamanan menjaga naskah soal Ujian Nasional (UN).

\section{DAFTAR PUSTAKA}

1. Alpurqon, Agung. "Sistem Pengendali Pintu Pagar Secara Otomatis Menggunakan Aplikasi Voice Command Pada Smartphone Android OS". Sekolah Tinggi ManSajemen Dan Ilmu Komputer (STMIK) RAHARJA. Tangerang, Indonesia. 2014

2. Arif, Mohammad. "Desain Prototipe Smart Voice Device Pintu Ruangan Menggunakan Raspberry Pi Pada Perguruan Tinggi Raharja". Sekolah Tinggi Manajemen Dan Ilmu Komputer (STMIK) RAHARJA. Tangerang, Indonesia. 2014

3. Arduino. 2015. "Arduino Genuino". Diambil dari: https://www.arduino.cc_(Tanggal akses 22 Agustus 2015)

4. Bagenda, Dadan Nurdin. "Prototipe Sistem Keamanan Pintu Garasi Menggunkan Keypad Dengan Sensor Berbasis Mikrokontroler". STMIK LPKIA. Bandung, Indonesia. 2011

5. Feri, Djuandi. 2011. "Pengenalan Arduino". E-book. www.tobuku, Juli 2011

6. Hendru. "Perancangan Sistem Kontrol Pintu Gerbang Otomatis". Universitas Tarumanegara. Jakarta, Indonesia. 2012

7. Informatika. 2013. "Atikel Teknik Informatika dan Sistem Informasi". Diambil dari: http://informatika.web.id/category/prototype/ (Tanggal akses 22 Agustus 2015)

8. Ikhwandhia, Muthiah. "Prototype Pengaman Pintu Rumah Berbasis Mikrokontroler Atmega 16". Universitas Negeri Yogyakarta. Yogyakarta, Indonesia. 2014

9. Nedia, Rahayu Okte. "Sistem Pengontrolan Pintu Garasi Rumah Menggunakan Komunikasi DTMF Melalui Ponsel Berbasis Mikrokontroler ATmega32". Universitas Andalas. Padang, Indonesia. 2012

10. Riadi, Imam. "Prototipe Sistem Keamanan Pintu Ruangan Menggunakan Barcode Password Dan Pin Password". Universitas Ahmad Dahlan. Yogyakarta, Indonesia. 2014

11. Safaat, Nazarudin. 2011. "Android Pemrograman Aplikasi Mobile Smartphone dan Tablet PC Berbasis Android". Jakarta: Informatika

12. Seppiawan, Ashar. "Sistem Keamanan Pintu Pagar Otomatis Menggunakan Voice Recognition". Jurnal Mahasiswa Teub. Universitas Brawijaya. 2011

13. Surya, Dimas Adi. "Perancangan Dan Pembuatan Sistem Keamanan Pintu Ruangan Tempat Penyimpanan Barang Jaminan Menggunakan Radio Frequency Identification (RFID) Dan Short Message Service (SMS) Berbasis Mikrokontroler AT89S52”. Universitas Negeri Padang. Padang, Indonesia. 2012

14. Susaptoyono, Yogyo. 2012. "Bluetooth" .Yogyakarta: CV. Andi Offset

15. Undala, Figa. "Prototype Sistem Keamanan Pintu Menggunakan Radio Frequency Identification (RFID) Dengan Kata Sandi Berbasis Mikrokontroler". Universitas Tanjungpura. Pontianak, Indonesia. 2015 